\title{
Evaluation of Ruminally Degradable \\ Dietary Protein as a Nitrogen \\ Source for Rumen Microbes
}

\author{
Matanobu Abe, Masayuki Funaba, Tsunenori IRIKı, \\ and Akifumi OGAWA \\ School of Veterinary Medicine, Azabu University, \\ Sagamihara-shi 229
}

(Received May 8, 1992)

\begin{abstract}
Four male Holstein calves weighing $129 \mathrm{~kg}$ initially were used in a $4 \times 4$ Latin square design to evaluate ruminally degradable protein (RDP) or degraded intake protein (DIP) as a nitrogen (N) source for rumen microbes. Fach of four diets consisted of rice straw, flaked corn and soybean meal, and the crude protein (CP) content was adjusted to $10.2,11.5,12.8$ and $14.1 \%$ by adding $0,0.5,1.0$ and $1.5 \%$ urea, respectively. The N-balance and the TDN content of diets were determined at the level of $27 \mathrm{~g}$ diet $/ \mathrm{kg}$ body weight/d. The RDP intake estimated according to $\mathrm{ARC}$ was 5.2, 6.4, 7.7 and $8.9 \mathrm{~g} / \mathrm{MJ} \mathrm{ME}$, whereas the DIP intake estimated according to NRC was $4.4,5.7,6.9$ and $8.4 \mathrm{~g} / \mathrm{MJ} \mathrm{ME}$, with increase in the CP content or urea content of diets. The daily $\mathrm{N}$-retention incrcased with daily $\mathrm{N}$-intake, and the highest efficiency value of about 0.69 was obtained for the conversion of urea- $\mathrm{N}$ into microbial $\mathrm{N}$ in the rumen when the diet contained $12.8 \% \mathrm{CP}$. Assuming that the conversion efficiency of ordinary RDP or DIP is 0.9 , the conversion efficiency of urea- $\mathrm{N}$ was about $80 \%$ of that, in agreement with the estimate of ARC. On this occasion, $7.3 \mathrm{~g} \mathrm{RDP} / \mathrm{MJ} \mathrm{ME}$ or $6.5 \mathrm{~g} \mathrm{DIP} / \mathrm{MJ} \mathrm{ME}$ was considered to be adequate to the highest production of microbial protein in the rumen, provided that RDP or DIP originates only from ordinary feeds.
\end{abstract}

Anim. Sci. Technol. (Jpn.) 63 (12): 1240-1246, 1992

Key words: RDP, DIP. microbial protein, urea, dietary energy

Of the dietary crude protein (CP), ruminally degradable protein (RDP) defined by $\mathrm{ARC}^{3)}$, or degraded intake protein (DIP) defined by $\mathrm{NRC}^{9)}$, is allotted to rumen microbes as a nitrogen $(\mathrm{N})$ source. According to $\mathrm{ARC}^{3)}, 7.8 \mathrm{~g} \mathrm{RDP}$ is required per $M J M E$ for the highest production of microbial protein. However, the criterion seems too high to apply to the case where the ruminal degradability (dg) of CP in feeds shown by $\mathrm{NRC}^{9)}$ are used for calculation ${ }^{1}$, because many of those values including the dg of corn are much lower than the values shown by $\mathrm{ARC}^{33}$.
Urea is the most convenient source of $\mathrm{N}$ for rumen microbes, but it is not clear if urea-N is utilized as efficiently as $\mathrm{N}$ from ordinary RDP or DIP. The $\mathrm{ARC}^{3)}$ has adopted an efficiency value of 1.0 for the conversion of ordinary RDP into microbial protein, but 0.8 for the conversion of urea-N. On the other hand, $\mathrm{NRC}^{87}$ has adopted the conversion efficiency of 0.9 not only for ordinary DIP but also for urea-N.

The purpose of this work was to evaluate $\mathrm{RDP}$ or DIP as a $\mathrm{N}$ source for rumen microbes. The special interest was to determine (1) the 


\section{Ruminally Degradable Dietary Protein}

ratio of RDP or DIP to $\mathrm{ME}$ adequate to the highest synthesis of microbial protein, and (2) the conversion efficiency of urea- $\mathrm{N}$ into microbial protein.

\section{Materials and Methods}

Animals and experimental design: Four male Holstein calves were used in a $4 \times 4$ Latin square design of $2 \mathrm{wk}$ per period. Animals were individually stalled in metabolic cages, and feces and urine excreted in the last $4 \mathrm{~d}$ of each period were totally collected. The mean body weight of animals was 128.8 (SD 6.1 ) $\mathrm{kg}$ initially and 182.8 (SD 12.5) kg finally.
Diets : Ingredients and compositions of four diets are shown in Table 1. The diets consisted of rice straw, flaked corn and soybean meal in common, but the crude protein (CP) contents were adjusted to $10.2,11.5,12.8$ and $14.1 \%$ by adding $0,0.5,1.0$ and $1.5 \%$ urea in place of flaked corn.

According to $\mathrm{ARC}^{3)}$, the $\mathrm{dg}$ of $\mathrm{CP}$ in flaked corn, soybean meal and urea is $0.6,0.6$ and 1.0 , respectively. On the other hand, the values are $0.42,0.65$ and 1.0 , respectively, according to $\mathrm{NRC}^{9)}$. Leaving the RDP or DIP in rice straw out of consideration, the RDP content of diets was $5.9,7.3,8.7$ and $10.0 \%$ according to

Table 1. Ingredients and compositions of experimental diets

\begin{tabular}{|c|c|c|c|c|}
\hline & & & & \\
\hline & 1 & 2 & 3 & 4 \\
\hline Ingredient $(\%)$ & & & & \\
\hline Rice straw & 12.0 & 12.0 & 12.0 & 12.0 \\
\hline Flaked corn (FLC) & 77.4 & 76.9 & 76.5 & 75.9 \\
\hline Soybean meal (SBM) & 6.2 & 6.2 & 6.2 & 6.2 \\
\hline Urea & - & 0.5 & 1.0 & 1.5 \\
\hline $\mathrm{NaCl}$ & 2.2 & 2,1 & 1.9 & 1.9 \\
\hline $\mathrm{CaCO}_{3}$ & 1.8 & 1.8 & 1.8 & 1.8 \\
\hline $\mathrm{Na}_{2} \mathrm{SO}_{4}$ & - & 0.1 & 0.2 & 0.3 \\
\hline Vitamin A, D premix & 0.4 & 0.4 & 0.4 & 0.4 \\
\hline Composition $(\%):$ & & & & \\
\hline Moisture & 11.2 & 11.2 & 11.0 & 11,1 \\
\hline Crude protein (CP) & 10.2 & 11.5 & 12.8 & 14.1 \\
\hline $\mathrm{RDP} \uparrow$ & 5.9 & 7.3 & 8.7 & 10.0 \\
\hline DIP $\ddagger$ & 4.8 & 6.2 & 7.6 & 9.0 \\
\hline UDP § & 4.3 & 4.2 & 4.1 & 4.1 \\
\hline $\mathrm{UIP}$ & 5.4 & 5.3 & 5.2 & 5.1 \\
\hline Urea-CP & - & 1.5 & 2.7 & 4.2 \\
\hline Ether extract & 3.0 & 2.9 & 2.9 & 3.0 \\
\hline Crude fibre & 4.9 & 4.4 & 4.0 & 3.6 \\
\hline Crude ash & 4.5 & 4.5 & 4.3 & 3.9 \\
\hline Nitrogen-free extract & 66.3 & 65.5 & 65.0 & 64.3 \\
\hline
\end{tabular}

The premix contained 10,000 IU vitamin $A$ and 2,000 IU vitamin $D / g$.

$\uparrow$ Ruminally degradable protein calculated assuming the degradability of CP in FLC, SBM and urea as $0.6,0.6$ and 1.0 , respectively, acording to $\mathrm{ARC}^{31}$. The RDP in rice straw was excluded.

\$ Degraded intake protein caluculated assuming the degradability of CP in FLC, SBM and urea as $0.42,0.65$ and 1.0 , respectively, according to $\mathrm{NRC}^{91}$. The DIP in rice straw was excluded.

$\S$ Undegraded dietary protein obtained by UDP $=\mathrm{CP}-\mathrm{RDP}$.

* Undegraded intake protein obtained by UIP $=\mathrm{CP}-\mathrm{DIP}$. 
$\mathrm{ARC}$, and the DIP content was 4.8, 6.2, 7.6 and $9.0 \%$ according to NRC, with increase in the urea content of diets. The content of undegraded dietary protein (UDP) defined by $\mathrm{ARC}^{3}$, or undegraded intake protein (UIP) defined by $\mathrm{NRC}^{8,9)}$, was almost constant in every diet.

The diets were daily given at $27 \mathrm{~g} / \mathrm{kg}$ initial body weight in each period, resulting in the CP intake of $2.7,3.1,3.4$ and $3.8 \mathrm{~g} / \mathrm{kg} / \mathrm{d}$, the RDP intake of $1.6,2.0,2.3$ and $2.7 \mathrm{~g} / \mathrm{kg} / \mathrm{d}$, and the DIP intake of $1.3,1.7,2.1$ and $2.4 \mathrm{~g} / \mathrm{kg} / \mathrm{d}$, and further the urea-CP intake of $0,0.4,0.7$ and $1.1 \mathrm{~g} / \mathrm{kg} / \mathrm{d}$, respectively. Of the daily ration, four parts by weight were given at $08: 30$ and six parts by weight at $16: 30$ to prevent the remains of feeds as far as possible.

Energy content of diets: The TDN content was also determined in the $\mathrm{N}$-balance trial. The contents of $\mathrm{ME}$ were estimated from the TDN content according to $\mathrm{NRC}^{7)}$ by using the conversion coefficient of $15.13 \mathrm{MJ} \mathrm{ME} / \mathrm{kg}$ TDN, and from the constitution of diets according to $\mathrm{ARC}^{3)}$ by assuming the $\mathrm{ME}$ content of flaked corn and soybean meal as 13.5 and $11.1 \mathrm{MJ} / \mathrm{kg}$, respectively. In the latter case, the $\mathrm{ME}$ in rice straw was not taken into account. The former $M E$ value was designated as $M_{N}$, and the latter as $\mathrm{ME}_{\mathrm{A}}$.

Analyses: The $\mathrm{N}$ content of diets, feces and urine were determined by the KJELDAHL's method.

The results were subjected to one-way analysis of variance for a Latin square design according to the general linear models(GLM) procedure of SAS $^{10}$. Model sums of squares for the Latin square were animal, period and diet effects.

\section{Results}

The measured contents of TDN and estimated contents of $\mathrm{ME}_{\mathrm{A}}$ and $\mathrm{ME}_{\mathrm{N}}$ in the diets are presented in Table 2. The energy contents were almost similar in four diets. Consequently, the ratio of $\mathrm{RDP}$ or DIP to energy increased with an increase in additional urea.

The $\mathrm{N}$-balance is also presented in Table 2.

Table 2. Measured contents of TDN, estimated contents of ME and ratios of ruminally degradable protein(RDP) or degraded intake protein(DIP) to energy in diets, and the nitrogen(N)-balance (Mean values for 4 calves each)

\begin{tabular}{|c|c|c|c|c|c|c|}
\hline & \multicolumn{4}{|c|}{ Diet } & \multirow[b]{2}{*}{ SEM } & \multirow[b]{2}{*}{$\mathrm{P}<$} \\
\hline & 1 & 2 & 3 & 4 & & \\
\hline $\operatorname{TDN}(96)$ & 72.0 & 71.6 & 72.4 & 70.9 & 1.2 & NS \\
\hline $\mathrm{ME}_{\mathrm{A}}(\mathrm{MJ} / \mathrm{kg})$ & 11.4 & 11.4 & 11.3 & 11.2 & - & - \\
\hline $\mathrm{ME}_{\mathrm{N}}(\mathrm{MJ} / \mathrm{kg}) \dagger$ & 10.9 & 10.8 & 11.0 & 10.7 & 0.1 & NS \\
\hline RDP/TDN (g/kg) & 82 & 102 & 120 & 141 & 0.9 & 0.001 \\
\hline DIP/TDN（g/kg） & 67 & 87 & 105 & 127 & 0.7 & 0.001 \\
\hline $\mathrm{RDP} / \mathrm{ME}_{\mathrm{A}}(\mathrm{g} / \mathrm{MJ})$ & 5.2 & 6.4 & 7.7 & 8.9 & - & - \\
\hline $\mathrm{DIP} / \mathrm{ME}_{\mathrm{N}}(\mathrm{g} / \mathrm{MJ})$ & 4.4 & 5.7 & 6.9 & 8.4 & 0.05 & 0.001 \\
\hline $\mathrm{N}$-intake $(\mathrm{g} / \mathrm{d})$ & 62.19 & 71.09 & $\begin{array}{r}\text { alance- } \\
78.60\end{array}$ & 87.35 & 1.32 & 0.001 \\
\hline$N$ in feces $(g / d))$ & 17.21 & 17.27 & 17.10 & 18.95 & 0.62 & NS \\
\hline $\mathrm{N}$ absorbed $(\mathrm{g} / \mathrm{d})$ & 44.98 & 53.82 & 61.50 & 68.40 & 1.71 & 0.001 \\
\hline $\mathrm{N}$ in urine $(\mathrm{g} / \mathrm{d})$ & 12.66 & 19.40 & 24.43 & 31.21 & 1.59 & 0.001 \\
\hline $\mathrm{N}$-retention $(\mathrm{g} / \mathrm{d})$ & 32.32 & 34.42 & 37.07 & 37.29 & 2.22 & NS \\
\hline
\end{tabular}

NS, not significant $(P>0.20)$.

* Calculated from the constitution of diets according to $\mathrm{ARC}^{31}$.

$\dagger$ Estimated from the measured TDN content according to $\mathrm{NRC}^{\text {? }}$. 


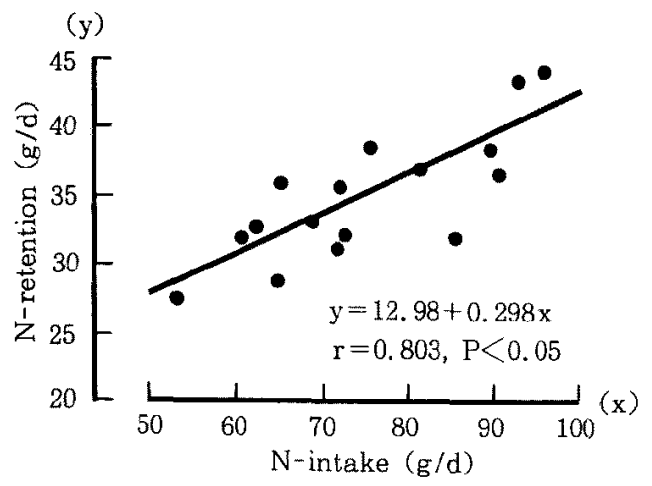

Fig. 1. Relation between the daily $\mathrm{N}$-intake and the daily $\mathrm{N}$-retention in total 16 calves.

The $\mathrm{N}$-intake, $\mathrm{N}$ absorbed and $\mathrm{N}$ excreted into urine increased linearely with increase in the dietary CP level, i.e. the urea content of diets $(p<0.001)$. Fecal $N$ was not affected by the dietary urea content. The N-retention tended to increase with the dietary urea content, though the difference among the diets was not significant. The non-significance would be due to a small number of animals as well as that $N$-retention was higher even when Diet 1 was given, probably because of an inclusion of soybean meal as a dietary component.

As shown in Fig. 1, however, a linear ( $y=$ $12.98+0.298 \mathrm{x})$ and a significant $(\mathrm{r}=0.803, \mathrm{p}<$ $0.05)$ correlation was observed between the daily $\mathrm{N}$-intake(x) and the daily $\mathrm{N}$-retention(y) when individual data for total 16 calves were used.

\section{Discussion}

Efficiency for the conversion of urea- $N$ into microbial $N$ : The conversion efficiency was obtained as the increment of microbial $\mathrm{N}$ per urea- $\mathrm{N}$ intake. The increments of microbial $\mathrm{N}$ were estimated from difference between $\mathrm{N}$ retention in animals fed Diet 1 and those fed Diets $2-4$ as follows :

$$
\mathrm{X}=\mathrm{Y} / \mathrm{UA} / \mathrm{DP} / \mathrm{PP}
$$

where $X$ is the increment of microbial $N(g / d)$ when Diets 2-4 were given, $\mathrm{Y}$ is the increment of N-retention when Diets 2-4 were given $(\mathrm{g} / \mathrm{d})$, UA is the utilization efficiency of absorbed microbial amino-N, DP is the true digestibility of microbial true protein, and $\mathrm{PP}$ is the proportion of protein- $\mathrm{N}$ in total microbial $N$. The values of $U A, D P$ and $P P$

Table 3. Estimated utilization of urea-nitrogen $(N)$ added to Diets $2-4$

\begin{tabular}{lccc}
\hline \hline & & Diet & \\
\cline { 2 - 4 } & 2 & 3 & 4 \\
\hline Urea-N ingested $(\mathrm{g} / \mathrm{d})$ & 8.90 & 16.41 & 25.16 \\
Urea-N absorbed $(\mathrm{g} / \mathrm{d}) \dagger$ & 8.84 & 16.52 & 23.42 \\
Apparent digestibility of urea-N (\%) & 99.3 & 100.7 & 93.1 \\
Urea-N retained (g/d) $\ddagger$ & 2.10 & 4.75 & 4.87 \\
Urea-N converted into microbial N (g/d) $8:$ & & & \\
$\quad$ According to ARC & 5.00 & 11.31 & 11.60 \\
$\quad$ According to NRC & 4.90 & 11.08 & 11.36 \\
Conversion efficiency of urea-N into microbial N*: & & & \\
$\quad$ According to ARC & 0.56 & 0.69 & 0.46 \\
According to NRC & 0.55 & 0.68 & 0.45 \\
\hline
\end{tabular}

The values were obtained as a difference from Diet 1 in $\mathrm{N}$-intake.

$\uparrow$ The values were obtained as a difference from Diet 1 in $\mathrm{N}$ absorbed.

t The values were obtained as a difference from Diet 1 in $\mathrm{N}$-retention.

$\S$ As for the calculation method, see the text.

Urea-N converted into microbial $\mathrm{N}$ per urea- $\mathrm{N}$ ingested. 
Table 4. Estimated ratio of $\mathrm{RDP} / \mathrm{ME}_{\mathrm{A}}$ or DIP/ME $/ \mathrm{E}_{\mathrm{N}}$ adequate to the highest production of microbial protein in the rumen

\begin{tabular}{|c|c|c|c|c|c|c|}
\hline & \multicolumn{4}{|c|}{$\begin{array}{c}\text { Value of the points on horizontal } \\
\text { axis in Fig. } 2(\mathrm{~g} / \mathrm{MJ})\end{array}$} & \multirow{2}{*}{$\begin{array}{l}\text { Equation of the } \\
\text { line } A \text { in Fig. } 2\end{array}$} & \multirow{2}{*}{$\begin{array}{l}\text { Value of } X \\
\text { in Fig. } 2 \\
(\mathrm{~g} / \mathrm{Mj})\end{array}$} \\
\hline & Diet 1 & Diet 2 & Diet & Diet 4 & & \\
\hline \multicolumn{7}{|c|}{ When the conversion efficiency of urea- $\mathrm{N}$ is equal to ordinary RDP or DIP : } \\
\hline $\mathrm{RDP} / \mathrm{ME}_{\mathrm{A}}$ & 5.2 & 6.4 & 3.7 & 8.9 & $y=22.37+1.901 x$ & 7.8 \\
\hline $\mathrm{DIP} / \mathrm{ME}_{\mathrm{N}}$ & 4.4 & 5.7 & 6.9 & 8.4 & $y=23.86+1.896 x$ & 7.0 \\
\hline \multicolumn{7}{|c|}{ When the conversion efficiency of urea $-\mathrm{N}$ is $80 \%$ ordinary RDP or DIP: } \\
\hline $\mathrm{RDP} / \mathrm{ME}_{\mathrm{A}}$ & 5.2 & 6.1 & 7.2 & 8.2 & $y=19.95+2.376 x$ & 7.3 \\
\hline $\mathrm{DIP} / \mathrm{ME}_{\mathrm{N}}$ & 4.4 & 5.5 & 6.4 & 7.6 & $y=21.79+2.358 x$ & 6.5 \\
\hline
\end{tabular}

were assumed as $0.75,0.70$ and 0.80 by $\mathrm{ARC}^{3)}$, and as $0.67,0.80$ and 0.80 by $\mathrm{NRC}^{8,9)}$, respectively. In this study, the both sets of figures were used for calculation, and the results are presented in Table 3.

The urea- $\mathrm{N}$ ingested was completely absorbed at least up to the daily intake of $16.41 \mathrm{~g}$ urea-N (Diet 3). The highest conversion efficiency of ingested urea- $\mathrm{N}$ into microbial $\mathrm{N}$ was also obtained when Diet 3 was given. The highest efficiency value calculated according to ARC (0.69) was quite similar to that calculated according to NRC (0.68).

According to $\mathrm{NRC}^{9}$, the efficiency for the conversion of urea- $\mathrm{N}$ into microbial $\mathrm{N}$ is 0.9 in common with ordinary DIP. On the contrary, $\mathrm{ARC}^{3)}$ has assumed the conversion efficiency of ordinary RDP as 1.0 , whereas that of urea-N as 0.8 , because urea lacks both sulfur and branched carbon-chains which are indispensable to the synthesis of microbial protein. In addition, degradation rate of urea in the rumen is much higher than that of soluble fraction of ordinary feed proteins ${ }^{2}$, which could also reduce the conversion efficiency of urea- $N$. More direct evidence for a deficient production of microbial protein when a high-urea diet was given was obtained in our previous work ${ }^{6}$.

The highest efficiency value obtained here (0.69) was about $70 \%$ of that assumed by
$\mathrm{ARC}^{3)}$ for ordinary RDP (1.0), but was almost equivalent to $80 \%$ of that assumed by $\mathrm{NRC}^{9)}$ for ordinary DIP (0.9). We agree with $\mathrm{ARC}^{3)}$ in respect of the viewpoint that urea- $\mathrm{N}$ is used only $80 \%$ as efficiently as $\mathrm{N}$ from ordinary RDP (DIP), although the conversion efficiency assumed by ARC for ordinary RDP seems too high.

Ratio of RDP or DIP to ME adequate to the highest production of microbial protein in the rumen: The adequate ratio was estimated as schematically shown in Fig. 2. Assuming that the production reached the highest when Diet 4 was given, and that the production increased linearly from Diet 1 to Diet 3 , the adequate ratio $X$ is obtained as a point of intersection between the two straight lines, $\mathrm{A}$ and $\mathrm{y}=37.19$

The results are presented in Table 4. Applying the ratios of $R D P / M_{A}$ and DIP/ME presented in Table 2 to the points on horizontal axis in Fig 1, 7.8 and $7.0 \mathrm{~g} / \mathrm{MJ}$ were adequate, respectively. The former value was identical to that recommended by $\mathrm{ARC}^{3)}$. However, these values are based on the assumption that conversion efficiency of urea- $\mathrm{N}$ is equal to that of ordinary RDP or DIP. Provided that urea- $\mathrm{N}$ is used only $80 \%$ as efficiently as $\mathrm{N}$ from ordinary RDP or DIP, and that RDP or DIP originates only from natural feedstuffs, the value of $R D P / M E_{A}$ and $D I P / M E_{N}$ adeqate 


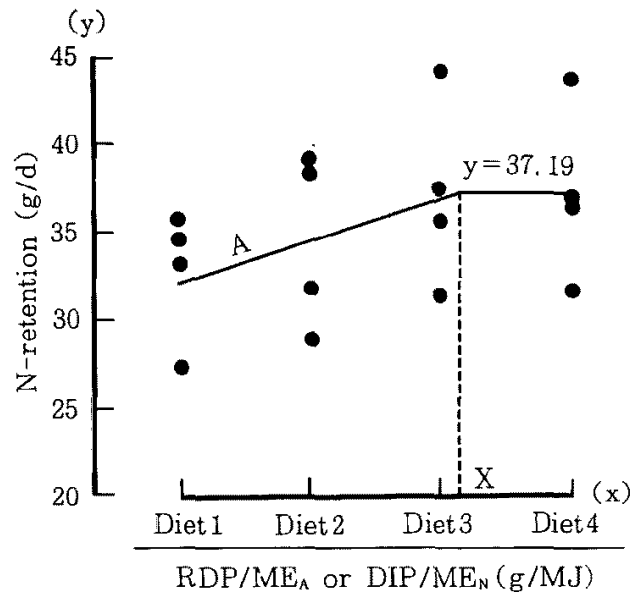

Fig. 2. A scheme for the estimation of $\mathrm{RDP} / \mathrm{ME}_{\mathrm{A}}$ ratio or $\mathrm{DIP} / \mathrm{ME}_{\mathrm{N}}$ ratio adequate to the highest production of microbial protein in the rumen.

to the highest synthesis of microbial protein would be 7.3 and $6.5 \mathrm{~g} / \mathrm{MJ}$, respectively (Table 4). Additionally speaking, the values did not vary so much, granted that the conversion efficiency of urea-N was $70 \%$ of that of ordinary RDP or DIP $(7.2$ and $6.3 \mathrm{~g} / \mathrm{MJ}$, respectively).

In our previous work ${ }^{5)}$ in which calves weighing more than $135 \mathrm{~kg}$ were given a low-lysine diet consisted of corn and corn gluten meal, the $\mathrm{N}$-balance was significantly improved by the administration of lysine via the esophageal groove when the daily CP intake per body weight was $3.0 \mathrm{~g} / \mathrm{kg}$ and the $\mathrm{RDP} / \mathrm{ME}$ ratio was $4.4 \mathrm{~g} / \mathrm{MJ}$. Because of the absence of $\mathrm{dg}$ value for corn gluten meal from $A R C$, the ratio was in fact the DIP/ME $\mathrm{N}_{\mathrm{N}}$ ratio estimated according to NRC, suggesting a limited synthesis of MCP in the rumen. The DIP provided by $3.0 \mathrm{~g} \mathrm{CP}$ having a dg value of $x$ is equal in amount to that provided by $4.0 \mathrm{~g} \mathrm{CP}$ having a $\mathrm{dg}$ value of $3 x / 4$. The higher the daily $\mathrm{CP}$ intake is, the lower $\mathrm{dg}$ valur is required of dietary $\mathrm{CP}$ to maintain the $\mathrm{DIP} / \mathrm{ME}_{\mathrm{N}}$ ratio that limits MCP synthesis. In our preceding works ${ }^{4,5)}$ using calves weighing more than 90 $\mathrm{kg}$, the lysine administration via the esophageal groove or via the duodenal cannula did not affect the $\mathrm{N}$-balance when the daily $\mathrm{CP}$ intake from low-lysine diets was 3.9 and $4.1 \mathrm{~g} / \mathrm{kg}$ and the DIP/ME $\mathrm{M}_{\mathrm{N}}$ ratio was 5.1 and $6.0 \mathrm{~g} / \mathrm{MJ}$, respectively, probably due to an increased production of MCP in the rumen.

\section{Acknowledgment}

This work was supported in part by a Grantin-Aid (No. 04660311) for Scientific Research from Ministry of Education, Science and Culture of Japan.

\section{References}

1) ABE,M., S. IRIE and T. IRIKI, Growth of calves receiving different proportions of rumen degradable protein ( $R D P$ ) and undegradable dietary protein (UDP). Anim. Sci. Technol. (Jpn.) 62 : 148-153. 1991.

2) ABE,M., T. IRIKI and N. YoshidA, Ammonia production from soluble- $\mathrm{N}$ fraction of various feedstuffs when incubated with rumen fluid. Anim. Sci. Technol. (Jpn.), 63: 721-727. 1992.

3) Agricultural Research Council, The Nutrient Requirements of Ruminant Livestock. Commonwealth Agricultural Bureaux. Lavenham. 1980.

4) IrIKI, T., K. AdAchi and M.Abe, Necessity of ruminally undegraded dietary protein in 4-5 months-old calves under the condition of low-protein intake. Anim. Sci. Technol, (Jpn.) 63: 414-419. 1992.

5) IRIKI, T., K. Morita and M. ABe, Limiting amino acids in calves above 3 months of age when a low-lysine diet was given. Anim. Sci. Technol. (Jpn.) 62: 572-578. 1991.

6) Iriki, T., T. Suganuma and M. Abe, On the necessity of nonmicrobial protein in male Holstein calves above $90 \mathrm{~kg}$ in body weight. Anim. Sci. Technol. (Jpn.) 62: 777-780. 1991.

7) National Research Council, Nutritional Requirements of Beef Cattle. 6th rev. ed. National Academic Press. Washington, D.C. 1984.

8) National Research Council, Ruminant Ni- 
trogen Usage. National Academic Press. Washington, D.C. 1988.

9) National Research Council, Nutritional Requirements of Dairy Cattle. 6th rev. ed. National Academic Press. Washington,
D.C. 1989.

10) SAS. User's Guide. Statistics. Statistical Analysis System Institute,Inc. Cary, N.C. 1985.

\title{
第一胃内微生物に対する窒素源としての第一 胃内分解性飼料蛋白質の評価
}

\author{
阿部又信・舟場正幸・ 入来常徳・小川晃史
}

麻布大学獣医学部，相模原市 229

\begin{abstract}
初体重 $129 \mathrm{~kg}$ のホルスタイン種雄子牛 4 頭を用い，4×4 ラテン方格法により第一䏣内微生物に対す る窒素 $(\mathrm{N})$ 源としての第一胃内分解性蛋白質（RDP または DIP）の評価を試みた。 4 種類の飼料は いず机も稻ワラ，圧片トウモロコシ抢よび大豆粕加ら成り，0，0.5，1.0 および $1.5 \%$ の尿素を添加す ることによって粗蛋白留（CP）含量をそれぞれ10.2，11.5，12.8および14.1\%に調整した．1日に 飼料を体重当り $2.7 \%$ 給与する条件で $\mathrm{N}$ 出納㧍よび TDN 含量を測定した。 その結果，ARC 飼養標 準に基づいて求めた ME $1 \mathrm{MJ}$ 当りの RDP 摄取量は, 飼料の $\mathrm{CP}$ 含量または尿䒺盆量の增加に伴っ て 5.2，6.4，7.7，8.9 g となり，NRC 標準に基いて求めた ME $1 \mathrm{MJ}$ 当りの DIP 摂取量は 4.4, $5.7 ， 6.9 ， 8.4 \mathrm{~g}$ となった. 1 日当りの $\mathrm{N}$ 保持量は $\mathrm{N}$ 摄取量とともに增加し，飼料の $\mathrm{CP}$ 含量が

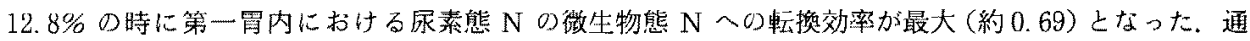
常の RDP または DIP の徽生物態蛋白質への転換効率を 0.9 とすると, 尿素態 $\mathrm{N}$ の転換効率はその 約 $80 \%$ に相当し，この值は $\mathrm{ARC}$ の見積りと一致した，その場合，RDP が通常飼料のみに由来する とすれば，第一胃内に和ける微生物態蛋白質合成を最大にするのに適当な RDP/ME 比は $7.3 \mathrm{~g} / \mathrm{MJ}$ となり, DIP/ME 比は $6.5 \mathrm{~g} / \mathrm{MJ}$ となった。
\end{abstract}

日蓄会報，63 (12)：1240-1246，1992 